\title{
Abrasive Wear Resistance of Wood
}

Milan Brožek

Czech University of Life Sciences Prague, 16521 Prague 6 - Suchdol, Czech Republic, Phone: +420 22438 3265, E-mail: brozek@tf.czu.cz

\section{Acknowledgement \\ Supported by the Internal Grant Agency of the Czech University of Life Sciences Prague, Prague, Czech Republic; Project No. 2014:31140/1312/3133.}

\section{References}

[1] BLAU, P. J. (1992). ASM Handbook, Volume 18 - Friction, Lubrication, and Wear Technology. ASM International. Online version available at: http://app.knovel.com/hotlink/toc/id:kpASMHVFL2/asm-handbook-volume-18. Acessed 10 November 2013.

[2] BROŽEK, M. (2012). Wear resistance of multi-layer overlays. In.: 11th International Scientific Conference Engineering for Rural Development. 24-25. May, 2012. Latvia: Jelgava, 210 - 215. Available online: http://tf.llu.lv/conference/proceedings2012/. ISSN 1691-5976.

[3] BROŽEK, M. (2007). Technicko-ekonomické hodnoceni aplikace návarů u plužních čepeli (Technical-economical evaluation of the overlays application on plough shares). Acta Univ. Agric. et Silvic. Mendel. Brun., 55, 4: 129-136. In Czech. ISSN 1211-8516.

[4] BROŽEK, M. (2014). Selected plastics wear resistance to bonded abrasive particles compared to some ferrous materials. Acta Univ. Agric. et Silvic. Mendel. Brun., 62, x: xxx-xxx. ISSN 1211-8516. In press.

[5] BROŽEK, M., NOVÁKOVÁ, A. (2008). Evaluation of sintered carbides wear resistance. In.: 7th International Scientific Conference Engineering for Rural Development. 29-30 May, 2008. Latvia, Jelgava, 209-213. Available online: http://tf.llu.lv/conference/proceedings2008/. ISBN 1691-5976.

[6] BROŽEK, M., NOVÁKOVÁ, A., MIKUŠ, R. (2010). Study of wear resistance of hard facings using welding powders on the NiCrBSi basis. In.: 4th International Conference Trends in Agricultural Engineering 2010. 7-10 September, 2010. Prague: Czech University of Life Sciences Prague, 115-118. ISBN 978-80-213-2088-8.

[7] BUDINSKI, K. G. (1997). Resistance to particle abrasion of selected plastics. Wear. 203-204. 302-309.

[8] CIESLAR, J., BROŽEK, M., BEDNÁŘ, B. (2013). An experimental assessment of special metal castings in reducing abrasive wear. Manufacturing Technology. 13, 4: 423-428. ISSN 1213-2489.

[9] FAHERTY, K. F., WILLIAMSON, T. G. (1995). Wood engineering and construction handbook 2. ed. New York: Osborne-McGraw-Hill. ISBN 0-07-019911-6.

[10] Friction and Wear Testing. American Society for Testing and Materials (1987). West Conshohocken, PA: American Society for Testing and Materials. 186. ISBN 0-87170-617-2.

[11] KAFKA, E. (1989). Dřevařská př́ručka (Woodworking guide). 1. vyd. Praha: Nakladatelství technické literatury. 483.

[12] KETTUNEN, P. O. (2006). Wood: Structure and properties. Uetikon-Zuerich ; Enfield: Trans. Tech. Publ. 401. ISBN 0-87849-487-1.

[13] KRÁL, P., HRÁZSKÝ, J. (2008). A contribution to the resistance of combined plywood materials to abrasion. Journal of Forest Science, 54, 1, 31-39.

[14] Lever, A. E, Rhys, J. A. (1968). The properties and testing of plastic materials. 3rd Ed. Bristol: Wright Temple Press Books. 445.

[15] LIU, Z. D., WANG, W. B., CAI, L., GUO, D. J., DAI, Z. D. (2012). Friction and wear properties of commercial solid wood floorings. Mocaxue Xuebao (Tribology). 32, 6. 557-562.

[16] OHTANI, T., YAKOU, T., KITAYAMA, S. (2001). Two-body and three-body abrasive wear properties of Katsura wood. Journal of Wood Science, 47, 2, 87-93.

[17] OHTANI, T., YAKOU, T., KITAYAMA, S. (2002) Effect of annual rings on abrasive wear property of wood. Journal of Wood Science, 48, 4, 264-269. 
[18] OHTANI, T., KAMASAKI, K., TANAKA, C. (2003). On abrasive wear property during three-body abrasion of wood. Wear, 255, 1-6, 60-66.

[19] PESCHEL, P. (2002). Dřevařská přiručka. Tabulky. Technické údaje (Woodworking guide. Tables. Technical data). Praha: Sobotáles. 318. ISBN 80-85920-84-0

[20] PLUHǍ̌, J. et al. (1989). Nauka o materiálech (Material Science). Praha: SNTL. 552.

[21] SLAVID, R. (2009). Wood architecture. Paperback ed. London: Laurence King. 239. ISBN 978-1-85669-606-7.

[22] TSOUMIS, G. (1991). Science and technology of wood: Structure, properties, utilization New York: Chapman \& Hall. 494. ISBN 0-412-07851-1.

[23] Vocel, M. (1983). Experimentální metody hodnocení tření a opotřebení (Experimental Methods of Friction and Wear Evaluation). Kovové materiály, 21, No. 6, 711-722. (in Czech). ISSN 0023-432X.

[24] Vocel, M., Dufek, V. et al. (1976). Tření a opotřebení strojnich součástí (Friction and Wear of Machine Parts). Praha, SNTL. 376 p.

[25] ZAHRADNÍČEK, V., HORÁK, P. (2007). Moderní dřevostavby (Modern wooden houses). 1. vyd. Brno: ERA. 155. ISBN 978-80-7366-109-0.

[26] ČSN 01 5050. Opotřebení materiálu (Wear of materials). Názvosloví (Terminology). 1969. (in Czech).

[27] ČSN 01 5084. Stanovení odolnosti kovových materiálů proti abrazívnímu opotřebení na brusném plátně (Determination of metal materials resistance against wear by abrasive cloth). 1974. (in Czech).

[28] ČSN 49 0134. Drevo. Metóda zistovania odolnosti proti oderu (Wood. Determination of abrasion resistance). 1984. (in Slovak).

[29] ČSN EN 13696. Wood flooring - Test methods to determine elasticity and resistance to wear and impact resistance. 2009.

[30] ČSN 91 0276. Nábytek. Metoda zjištování odolnosti povrchu proti otěru (Furniture. Method of determining the surface resistance to abrasion). 1989. (in Czech). 